\title{
Bedensel Deneyime Dayalı Yer Bilgisinin Yeniden Yapılandırılması İçin Bir Yöntem İrdelemesi: Deneyimsel Haritalama
}

\author{
A Methodological Inquiry for Re-structuring Spatial Knowledge \\ Derived From Bodily-Experience: Experiential Mapping
}

Derya YORGANCIOĞLU, ${ }^{1}$ ㅇ Işıl ÇALAK ${ }^{2}$

ÖZ

Bu makalede "Re-Mapping the Visibles and Invisibles of Vefa-Zeyrek-Fener-Balat" adlı çalıştayın kavramsal çerçevesi ve bulgularına yer verilmiştir. Çalıştay öncelikle, mimarlık eğitiminin okul mekânını aşarak gerçek hayata dokunmasını, öğrencilerin yer, kent ve bedenle etkileşimlerinin artırılmasını ve mekân kavramına ilişkin özgün bir bakış ve algı kazanmalarını hedeflemiştir. Çalıştayın kavramsal çerçevesi bedensel deneyimin yer olgusunu tanımlamadaki rolü ve kentlerin görünen ve görünmeyen bileşenleri bağlamında bedenin deneyimlediği mekân üzerine odaklanmaktadır. İstanbul'da mimari, tarihi ve kültürel çok katmanlılığı nedeniyle Vefa-Zeyrek-Fener-Balat semtlerinden oluşan bir güzergâh çalışma alanı olarak seçilmiştir. Bedensel-duyusal algı eylemini mekân deneyiminin odağına oturtarak, kent mekânının görünür olan ve görünür olmayan unsurlarına dair bilgi katmanlarının açığa çıkarılması amaçlanmıştır. Bağlamın özgünlüğü çalıştayın yöntemsel yaklaşımıyla örtüşmüştür. Çalıştay günlük yaşam döngüsünde yerin deneyimlenmesi, deneyim bilgisinin kaydedilmesi, kaydedilen bilginin parçalanarak yeniden yorumlanması ve 2 ve 3 boyutlu deneyim haritaları oluşturulması aşamalarını kapsamıştır. Deneyim haritası, fenomenolojik bir bakış açısıyla, yer ve mekân bilgisinin yeri deneyimleyen beden-özneler tarafından kurgulanmasını ve temsil edilmesini içeren bir yaklaşım olarak benimsenmiştir. Buna göre beden-öznelerin bireysel olarak edindiği ve kaydettiği beneyim bilgisi, daha sonra grup çalışması aracılığıyla üretilen bir tasarım bilgisine dönüşmüştür. Bu tasarım bilgisi kent katmanlarının üst üste geldiği ve/veya iç içe geçtiği bir örüntüyle oluşturulan deneyimsel haritalarda ifade bulmuştur.

Anahtar sözcükler: Bedensel deneyim; deneyimsel haritalama; tasarım eğitimi; fenomenoloji; yer bilgisi.

\section{ABSTRACT}

This paper discusses the integrated study of the workshop entitled "Re-Mapping the Visible and Invisible of Vefa-Zeyrek-Fener-Balat" and the conceptual theory behind it. Encouraging students to look beyond the boundaries of studio environment and explore the disclosed features of urban space have been a crucial part of this workshop. The conceptual framework of the workshop is based on the role of bodily experiences in defining the phenomenon of space in the context of visible and invisible features of the city. Vefa-Zeyrek-Fener-Balat districts in Istanbul is selected as a route to present architectural, historical and cultural; multi-layered nature of the field. Considering the bodily-sensory perception at the center of spatial experiences, the aim was to uncover layers of those sensual experience related to urban space. The authenticity of the methodological approach is to address the stages of urban space experience, to record the knowledge gained through this experience, and to express it through two-dimensional posters and three-dimensional models. Within phenomenological perspective, experiential mapping is adopted as an approach of structuring and representing spatial knowledge by body-subjects who themselves experience the place. Spatial knowledge acquired and represented by body-subjects is then transformed into design knowledge generated by/through group-works. Consequently, this design knowledge has been made visible as a solid material such as maps and posters enabling us to read the patterns of overlapping and intersecting layers of urban spaces.

Keywords: Bodily experience; experiential mapping; design education; phenomenology; spatial knowledge.

'Özyeğin Üniversitesi Mimarlık ve Tasarım Fakültesi, Mimarlık Anabilim Dalı, İstanbul

²Diablo Valley Koleji Mimarlık ve Mühendislik Bölümü, Pleasant Hill California, Amerika Birleşik Devletleri

Başvuru tarihi: 07 Ocak 2019 - Kabul tarihi: 12 Şubat 2020

İletişim: Derya YORGANCIOĞLU. e-posta: derya.yorgancioglu@ozyegin.edu.tr

○ 2020 Yıldız Teknik Üniversitesi Mimarlık Fakültesi - ๑ 2020 Yıldız Technical University, Faculty of Architecture 


\section{Giriş}

Bu çalışmada yerin beden üzerinden deneyimlenmesi ve deneyime dayalı bilginin yeniden üretilmesi için bir yöntem olarak deneyimsel haritalama üzerinde durulmakta ve bu yöntemin uygulandığı bir çalıştayın süreci ve bulguları tart-şılmaktadır. Çalışmanın kavramsal çerçevesi fenomenolojik bir bakış açısıyla güncel beden kuramlarına temellendirilmekte, nasıl bir beden sorusundan yola çıkılarak nasıl bir mekân sorusuna bütüncül bir bakış açısıyla yanıt aranmaktadır. Zihin ve bedenin, düşünce ve algısal deneyimin birbirinden ayrı tutulduğu düalistik paradigmalara eleştirel bir yaklaşımla, bedenin ve algının bütünselliği vurgulanmakta, bedenin mekânla kurduğu etkileşimin durumsallığı araştrılmaktadır. Bu durumsallık, farklı deneyimleme ve algılama stratejileri aracılığıyla yer bilgisine ulaşmanın ve bu bilgiyi yeniden üretmenin bir yolu olarak irdelenmektedir. Çalışma mimarlık öğrencileri için beden ile çevresi arasındaki ilişkiye dair bir araştırma alanı sunmaktadır. Yöntemsel çerçevenin temellendiği deneyimsel haritalama, güncel mimarlık eğitimi uygulamaları ve araştırmalarında sıkça yer bulmaktadır (Güney \& Arıdağ, 2011; Kürkçüoğlu \& Ocakçı, 2015; Aydınlı \& Kürtüncü, 2014). Deneyim haritaları, mekânın görünür olan ve görünür olmayan verilerinin bedensel deneyim yoluyla keşfedilmesi, deneyim bilgisinin farklı temsil araçlarıyla yeniden üretilerek somutlaştırılmasına yönelik alternatif tasarım stratejileri geliştirilmesine olanak tanımaktadır.

\section{Beden-Mekân-Algı İlişkisi}

Beden olgusu bir 'dünyada varoluş biçimi' olarak fenomenolojik tartş̧maların odağındadır. Bu tartışmalarda beden aracılığıyla var olmamın doğası gereği mekânsal bir boyut taşıdığı vurgulanır. 20. yy. varoluşçu felsefe alanının önde gelen isimlerinden Maurice Merleau-Ponty (2002, s. 342)'ye göre "mekân varoluşsaldır; varoluş da mekânsaldır." Bedenle mekânın bir aradalığı "ayrılmaz bir şekilde birbiriyle ilişkili" olma durumuna işaret etmektedir (Merleau-Ponty, 2002). Merleau-Ponty'nin altnnı çizdiği mekânsal bedenin dünya ile kurduğu ilişki algı, duyum ve deneyim temelinde gerçekleşir. Bedenin algısal ve duyumsal deneyimleri görsel, dokunsal, işitsel olguları içeren çok boyutlu bir durum olarak ele alınırken, bu çok-boyutluluk, parçaların toplamından fazlasına, farklı duyuların birbirinden ayrıştırılamayacağı bir bütünselliğe işaret eder. Algı, beden-öznenin duyular yoluyla mekândan bilgi edinmesi eylemi olarak tanımlanabilir. Algı ve duyuma dayalı deneyim, beden ve mekân arasında dolaysız bir bağıntı kurulmasına zemin oluştururken, bedenin mekânı idrak etmesinin ve anlamlandırmasının da başlıca yolu olarak görülür. Buna göre, 'deneyimleyen beden' ve 'deneyimlenen mekân' birbirleriyle iç içe geçen olgulardır. Bedenin deneyimlediği sadece mekân değil, kendi mekânsalığıdır. Deneyimin, mekâna dair bilgiye ulaşmada "çok katmanlı mekân oluşumunu" temsil ettiğini belirten Aydınlı $(2008$, s. 152) bu du- rumu şöyle açıklar: "[M]ekânı salt betimlenen nesne özellikleriyle değil, aynı zamanda da betimleyen konumundaki öznenin anlama ve açıklama ediminin birbirini görünür kılan ilişkisi bağlamında, ..., deneyimlemek olasıdır." Nasıl bir beden sorusuna verilen yanıt, bağlamından kopartilarak nesnelleştirilemeyen, zaman-mekân bağlamında var olan ve bu varoluşunu bedensel-algısal deneyim üzerinden gerçekleştiren bir bedendir. Nasıl bir mekân sorusuna yanıt olarak ise bedensel deneyimle yeniden kurulan ve anlamlandırılan, "herkse için eşit nesnellikte olmayan, ilişkisel ve durumsal mekân" (Pallasmaa, 2005) yanıt verilebilir.

\section{Mekânsal Algının Zamansallığı}

Beden ve mekânın algısal deneyim temelinde iç içe geçme hali "durumun mekânsallı̆̆ı" (spatiality of situation) kavramıyla açıklanır (Şekil 1). Bedenin belli bir zamanda ve mekânda deneyimledikleri belli bir duruma işaret eder; bu durum biriciktir. Bedenin mekânla karşılaşmalarının çokluğu, her bir karşılaşmayı farklılaştırır, farklı karşılaşma olasılıkları potansiyeli taşır. Aydınlı (2008) bunu "algılayan ile algılananın durumsal birlikteliği" olarak tanımlar. Durumun mekânsallığı tartışmalarında "kendini dünyayla geçtiği her temasta yeniden kuran çoklu bir beden anlayışı"nın örtük olarak var olduğu söylenebilir (Duru, 2018).

Fenomenolojik beden mekânsal olduğu kadar zamansaldır. Burada sözü edilen zaman, soyut bir kavram olmaktan öte, algıya ve duyuma dayalı bedensel deneyimlerin getirdiği "yaşanmış zaman" (lived-time) olarak tanımlanan bir olgudur (Merleau-Ponty, 2002). Zaman bir diğer ifadeyle "mekânsal olanı içselleştiren bir an"dır (Aydınlı, 2008, s. 155). Buna paralel olarak mekân da salt fiziksel mekân değil, bedenin bağlanmış olduğu "yaşanmış-mekân" (livedspace) olarak adlandırılır. Bedenin algısal deneyimlerinin mekân ve zaman boyutlarını Merleau-Ponty şöyle açıklar: "Ben [beden] mekânda ve zamanda değilim, ne de mekânı

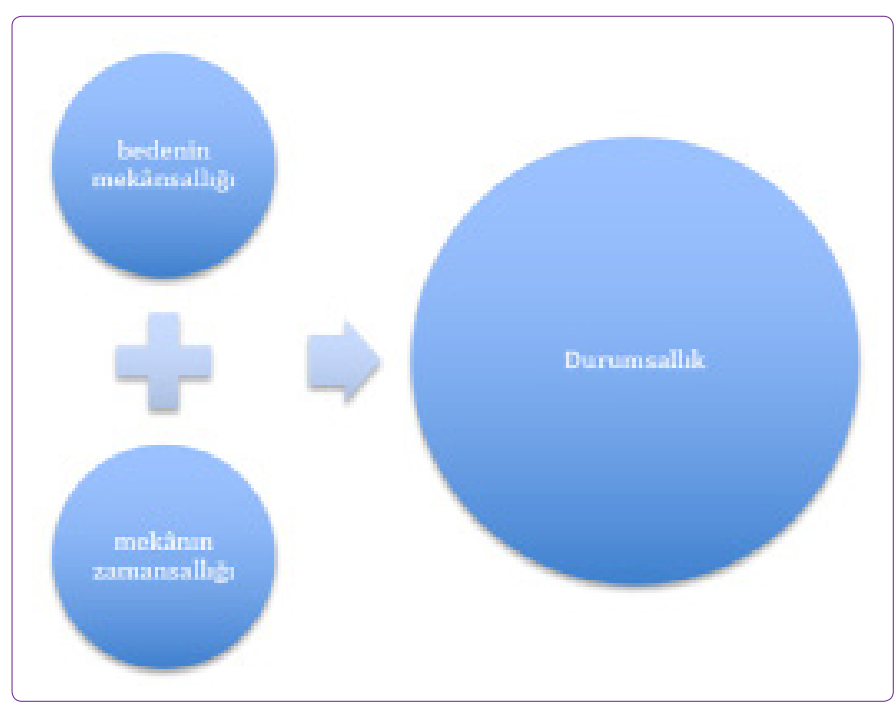

Şekil 1. Durumun kekansallığı şeması. 
ve zamanı idrak ederim; ben onlara aitim, bedenim onlarla bütünleşir, onları barındırır. Bu barındırmanın kapsamı, kendi varlığımın da ölçüsüdür..." (Merleau-Ponty, 2002, s. 162).

Mimarinin insan hayatını şekillendirme potansiyelinin bu deneyimsel ve zamansal boyutta yattı̆ının altı çizilmektedir. Fenomenoloji okumalarını tasarım yaklaşımının temeline oturtan mimar Steven Holl, mimarinin zaman boyutunun ancak mekânsal olarak algılanabileceğine işaret eder. Mekânı deneyimleyen beden zaman olgusunu keşfederken mekân da yaşanmış mekân olur: "Beden-özne, belli bir zamanda var olurken, mekân algılanan bir süreyle ilişkilenir... Algı ve idrak, mimari mekânın hacmi ile zamanın idraki arasında bir denge kurar" (Holl, 2000, s. 13). Benzer şekilde Juhani Pallasmaa (1998) mimarlığın yer ve mekâna dair özgünlük ortaya koyması ve böylece dünyevi bir sürekliliğin deneyimini hissettirmesi gerektiğinin altını çizer.

\section{Duyuların Mekânsal Algıdaki Rolü}

Fenomenoloji tartışmalarında algı, bedensel varlığın bütün duyularını aktive eden bir deneyim olarak tanımlanır. Gözle görülen, temas edilen, duyulan ve hatta tadılan şeylerin tümü bedenle hissedilen bütüncül bir olguya karşlık gelir. Merleau-Ponty (2002) bedensel varlığın dış dünyayla temas kurduğu ve kalıcı olarak kök saldığı bir "algı alanı" (perceptual field)'na işaret ederken, algının bütünsel bir yapısı olduğunu savunur. Merleau-Ponty'ye (2002) göre bu algı alanında görülenler ve duyumsananlar bir aradadır; ancak görsel deneyim ile dokunsal deneyim arasında farklılıklar vardır. Görsel algı doğasında bir "nesnellik" taşır; bu nesnellik beden-özne ile dış dünya, gören ile görülen arasında var olan mesafeye referansla açıklanır (Merleau-Ponty, 2002, s. 369). Dokunsal deneyim söz konusu olduğunda ise, beden-özne ve dış dünya arasında bir mesafeden bahsedilemez; beden dünyayla dolaysız bir temas kurar ve bu teması sağlayan sadece bir organ olarak eller değil, bedenin tamamıdır. Görsel ve dokunsal algı deneyimleri etkileşim halindedir; görülenler bedende dokunsal bir duyumsamayı aktive ederken, dokunsal deneyim bedenin görsel belleğinde de yansıma bulur.

Mimarlıktaki fenomenoloji tartşmaları, Pallasmaa (2014)'ya göre Kartezyen anlayışa temellenen ve gözü yücelterek görmeyi bilmekle eş tutan "gözmerkezci" (ocularcentrism) yaklaşıma karşıt olarak, algı ve duyum yoluyla gerçekleşen bedensel deneyimin çok-boyutlu ve bütünsel olduğu perspektifini getirmektedir. Buna göre mimarinin olgusal özellikleri salt görsel boyuta indirgenemez. Mekânı tanımlamayı ve üç boyutluluğunu idrak etmeyi sağlayan özellikler, malzeme, doku, ses, ışık ve sıcaklık düzeyi gibi diğer duyuları da aktive eden olgusal özellikleri kapsar (Hadjiphilippou, 2013). Dokunma duyusunun bedenin mekân algısında diğer duyulara göre daha etkili olduğu görüşü, dokunma duyusuna karşılık gelen Yunanca kökeni hapthai olan, günümüzdeki kullanımıyla haptic kavramına refe- ransla ele alınmaktadır. Duyusal deneyimlere ilişkin bütünsel bir perspektif sunan haptic kavramı "dokunma duyusu, pozisyonel farkındalık, denge, ses, hareket ve geçmiş deneyimlerin belleği gibi pek çok duyunun bir araya getirilmesi" olarak değerlendirilmektedir (O'Neill, 2001, s. 4). Kennedy ve Juricevic (2003), haptic alanını, "elle dokunulur/tutulur olanın bilimi" şeklinde tanımlanmaktadır.

Dünyayla ilişki kurma biçimimizin daha çok görsellik üzerinden tanımlandığı günümüzde zihin-beden-çevre arasındaki ilişkinin yeniden güçlendirilmesi gerektiğini savunan Holl, görsel alanda zihnin, bedensel duyular aracilığıyla temas kurduğumuz olgulardan ayrıştrılamayacağını vurgular (Holl, 1998; Holl, Pallasmaa, \& Pérez- Gómez, 2006). Holl mimarinin malzemeye dayalı fiziksel gerçekliğinin salt görsel deneyim yoluyla algılanamayacağı, mimariyi algılayan bedenin mekânsallığı ve zamansallığı gözetildiğinde, görme, dokunma, işitme ve diğer bütün duyuların aktive olduğu çok boyutlu bir haptic alandan söz edilebileceğini belirtir (Holl, 1998, s. 16). Pallasmaa (2003, s. 65) hapticity kavramını "görmenin bilinçsiz hali" olarak tanımlar: buna göre görme duyusu malzemenin üç boyutluluğunu algılamamızı sağlayacak veri sağlar; "yüzey dokusunun, ısının ve ağırlığın bilinçsiz okumasını" kapsar. Pallasmaa (2012, s. 66) bunu bir heykelttraşın ellerinin aynı zamanda onun gözleri olduğu benzetmesiyle açıklar; bir heykelttraş heykel yaparken ellerini "idrak etme ve düşünme organizması" olarak kullanır. Pallasmaa (1998) ayrıca, yaşadığımız çağın "hız kültürü" ile şekillendiğini ve bunun görsel mimariyi ön plana çıkardığını, buna karşın dokunma duyusu aracılığıyla deneyimlenen haptic mimarinin yavaşlık ve derinlik olgularını barındırdığını düşünür; dokunmaya dayalı mimari deneyimin mekânla beden arasında öznel bir bağ kurulmasını da sağladığını savunur. Bu bağ, bedenin dokunarak deneyimlediği mekâna dair bilgisinin bağlam ve geçmiş deneyimlerle ilişkilenmesiyle de açıklanabilir (Klatzky \& Lederman, 1995) (Şekil 2).

\section{Çalışmanın Amacı ve Kapsamı}

$\mathrm{Bu}$ çalışmanın amacı, mimarlık eğitiminin stüdyo mekânını aşarak gerçek hayata dokunmasını, öğrencilerin yer ile, kent ile, beden ile etkileşimlerinin artrılımasını ve mekân kavramına ilişkin daha özgün bir bakış ve algı kazanmalarına katkı sağlamayı hedefleyen "Re-Mapping the Visibles and Invisibles of Vefa-Zeyrek-Fener-Balat" adlı çaış̧tayın yöntem önerisi ve bulgularını tartışmaktır. Makaleye konu olan ve Mimarlık Bölümü ve iç̧ Mimarlık ve Çevre Tasarımı Bölümünden öğrencilerin katılımıyla gerçekleştirilen çalıştayın kavramsal çerçevesi genel olarak iki ana başlık altında şekillenmiştir. ${ }^{1}$ Bunlardan ilki, bedensel deneyi-

\footnotetext{
1 Kathlımcı öğrenciler: Aykut Yıldız, Bercis Yılmaz, Buse Şengür, Büşra Kara, Ceren Karadağ, Eylül Tuncay, Ezgi Özdal, Livza İlayda Balkan, Melike Gamze Güler, Meryem Kahya, Muazzez Ceren Koçyiğit, Onur Alan, Onur Vayvalak, Ömer Odabaş, Ömer Faruk Taşkale, Seyide Zeynep Şen, Sezen Kör, Su Eda Temizel, Sultan Murat Yılmaz, Zeynep Hazal Tokmak.
} 


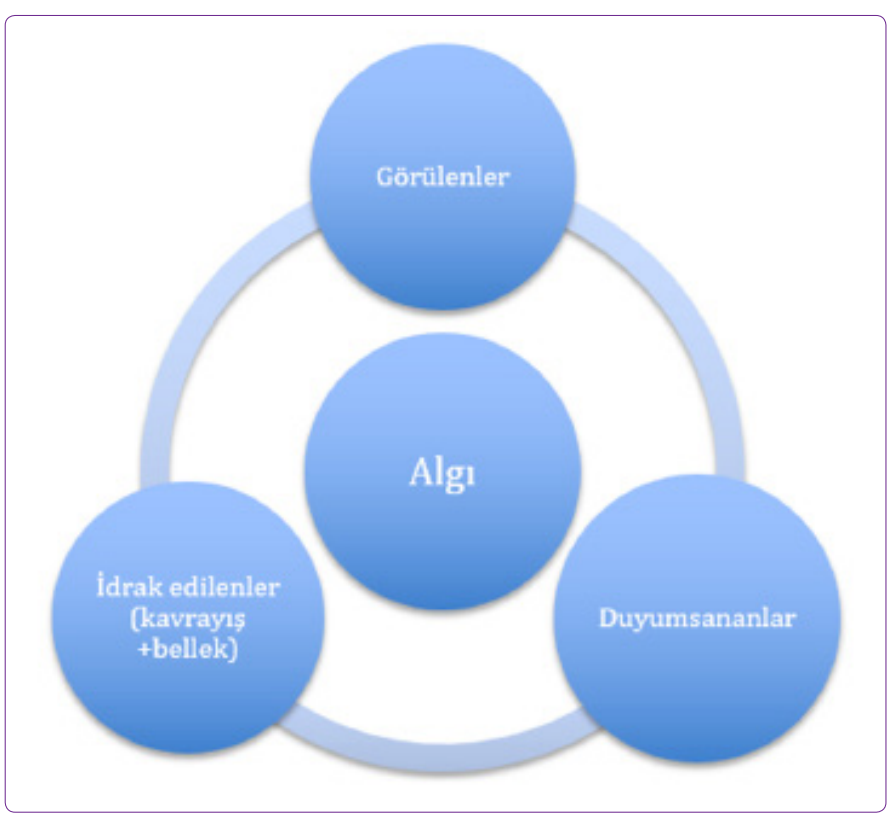

Şekil 2. Algı şeması.

min yer olgusunu tanımlamadaki rolüdür. Öğrencilerden süreç boyunca 'nasıl bir beden?' sorusuna yanıt aramaları beklenmiş, bu doğrultuda bedensel duyularımızın yerin deneyimlenmesi eylemini ne şekilde etkilediği irdelenmiştir. İinci olaraksa 'bedenin deneyimlediği mekân' olgusu odağında 'nasıl bir mekân?' ve 'nasıl bir kent?' soruları ele alınmıştır. Çalışmada, fenomenolojik bir perspektifte bedensel-duyusal algı eylemini mekân deneyiminin odağına oturtarak kent mekânının 'görünür olan' ve 'görünür olmayan' unsurlarına dair bilgi katmanlarını açığa çıkarılması amaçlanmıştir.

Çalıştay bedensel deneyimin yer olgusunu tanımlamadaki rolünden sonra, 'bedenin deneyimlediği mekân' olgusu üzerine odaklanmıştır. Bu durumda 'nasıl bir beden?' sorusu, 'nasıl bir kent?' ve 'nasıl bir mekân?' sorularına dönüşmektedir. Kentlerin görünen ve görünmeyen bileşenlerinin sorgulanması amaçlanmış; yapıların, sokakların, meydanların ve bunların içerisinde/arasında hareket halindeki insanların/hayvanların tekil fiziksel varoluşlarının ötesinde, bunlara anlam katan bütünselliğin fark edilmesi hedeflenmiştir. Kentin görünmeyen boyutları görünenler arasındaki bağ dokular gibi düşünülebilir. Bu bağ dokular, kent mekânındaki geçmiş yaşanmışlıklardan ve bugün yaşananlardan oluşur. Geçen yaşamlar kentlerde izler bırakırlar, bir yaşam biçimi oluştururlar. Her tarihsel dönem, kendi yaşam organizasyonunu kent mekânına yansıttr ve bu organizasyon yıllar sonra kent üzerinde çeşitlenen birçok geçmiş anlatısına görsel olarak ışık tutar. Kentin belleği, hiç durmadan değişir, dönüşür (Çalak, 2013). Bütün bunları hissedebilmek, görebilmek ve fiziksel varoluşların ötesinde bu anlamları aramak, çalıştayda öğrencilerden beklenen bir yaklaşım olmuştur. Kentlerin anlamını veren bütünselliğin bu görünmeyen bileşenleri nelerdir, nasıl tanımlana- bilir soruları, çalıştay katılımcılarını tekrar bedene ve algılarına döndüren bir başlangıç noktası niteliği taşımaktadır.

Çalıştayda görsel algının günümüzdeki mekân deneyiminde baskın algı biçimi olmasına eleştirel bir pozisyon benimsenmiştir. Diğer duyuların da mekânı deneyimlememizde önemli rol oynadığına, kent mekânına dair deneyimlerimizin görsel algı yoluyla olduğu kadar koklama, dokunma, işitme ve hatta tat alma duyularını kapsayan deneyimler aracılığıyla gerçekleştiğine vurgu yapılmıştı (Şekil 3). Mimarinin deneyimsel boyutuna, biçim, malzeme, ışık, ses gibi duyusal uyaranların bedenin mekânı anlaması ve anlamlandırmasındaki rolüne dikkat çekilmiştir (Özcan, 2003; Yorgancıŏ̆lu, 2004).

Çalıştayda beden ve yer arasında görünmeyen bir etkileşim olduğu kabulünden yola çıkılarak bu etkileşimin görünür hale getirilmesi hedeflenmiştir. Beden-yer etkileşiminin çok katmanlılığına dikkat çekilmiş ve öğrencilerin mekâna dair algı alanlarını genişleterek, deneyim yoluyla oluşacak olan kavrayışı ve bilgiyi açığa çıkartmaları amaçlanmıştır. Böylece kent mekânını pasif birer gözlemci olarak değil, bedensel-duyusal algılarını etkinleştirebilen aktif birer katılımcı olarak deneyimlemeleri ve deneyim bilgilerini temsil edebilmeleri teşvik edilmiştir.

İstanbul'da Vefa-Zeyrek-Fener-Balat semtlerini kapsayan bir çalışma alanı belirlenmiştir. Vefa-Zeyrek-Fener-Balat semtlerinin doğası çalıştayın yer olgusunun görünür ve görünür olmayan unsurlarını içeren çok katmanlııı vurgusuyla örtüşmektedir. Alanın fiziksel yapısı kadar tarihsel, kültürel ve sosyal yapısının oluşturduğu çok katmanlıık, çalışma alanı olarak belirlenmesinde etkili olmuştur. İstanbul'un tarihi yarımadasında yer alan Vefa-Zeyrek-Fener-Balat semtleri, Bizans, Osmanlı ve 20. yy modern Türk mimarlığının örneklerinin günümüzde var olmaya devam ettiği ve aynı anda birçok katmanın deneyimlenebildiği bir alan olma niteliği taşımaktadır. Tarihsel niteliği olan sivil mimari örnek-

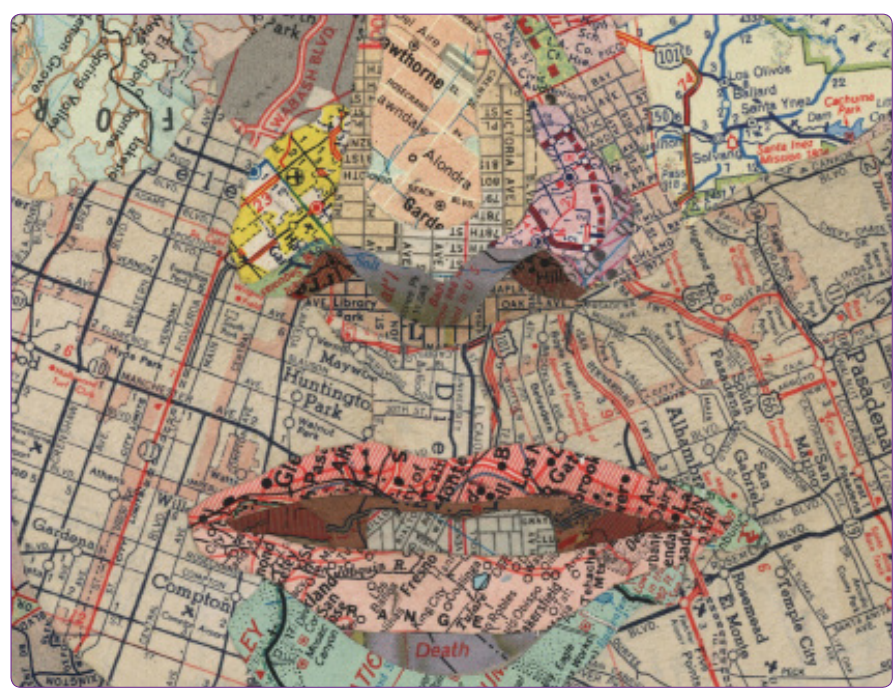

Şekil 3. Alberto Bustillos, Untitled_Urban Memory, 2008. 
Tablo 1. Çalışmanın yöntemsel aşamaları

$\begin{array}{ll}\text { Aşama 1 } & \text { Yere ait deneyim bilgisi } \\ \text { Aşama 2 } & \text { Deneyim lensleri (iz ve geçiş) } \\ \text { Aşama 3 } & \text { Deneyim bilgisinin kaydedilmesi } \\ \text { Aşama 4 } & \text { Kaydedilen deneyim bilgisinin yorumlanması } \\ \text { Aşama 5 } & \text { Malzeme seçimi/dönüştürme/detay çözme süreci } \\ \text { Aşama 6 } & \text { Birim tasarımı } \\ \text { Aşama 7 } & \text { Birimlerle } 2 \text { ve } 3 \text { boyutlu temsil oluşturma süreci: } \\ & \text { algı haritası }\end{array}$

lerinin yansıra, yakın döneme ait niteliksiz yapılaşmanın da gözlemlendiği çalışma alanı, ayrıca Molla Zeyrek Camii (Pantokrator Manastrı), Molla Hüsrev Camii, İstanbul Manifaturacılar Çarşısı (IMÇ) gibi dini ve kültürel mirasımızda önemli yeri olan yapılara ev sahipliği yapmaktadır. Çalışma alanının bir parçası olan Zeyrek, UNESCO tarafindan belirlenen "Dünya Miras Alanı" listesinde "İstanbul'un Tarihi Alanları" olarak yer alan dört bölgeden biri olma özelliği taşımaktadır (T.C. Kültür ve Turizm Bakanlığı, Ekim 2011).

\section{Çalışmanın Yöntemsel Çerçevesi}

Çalıştayın yöntemsel yaklaşımı yerin deneyimlenmesinden elde edilen bilgiye temellenmektedir. Yere ait deneyim bilgisi, yerin belli kavramsal lensler odağında deneyimlenmesiyle elde edilmektedir. Çalıştayın katılımcıları olan her bir beden-özne, kendi deneyimleri üzerinden bir mekânsal bilgi repertuvarı oluşturmaktadır; bu repertuvar malzeme, doku, renk, ışık, koku gibi fiziksel ve somut olgularla ilişkili olduğu kadar, somut olmayan olgularla da ilişkilenebileceği için özneldir, bağlamsaldır ve zaman odaklıdır; dolayısıyla değişkendir. Çalıştayda "deneyimsel haritalama" (experiential mapping) yöntemi kullanılarak bu alanların görünür olan ve görünür olmayan unsurlarının mekân deneyimi sürecinde bedensel duyular aracılı̆̆ıyla yeniden keşfedilmiştir. Çalıştay (i) yerin deneyimlenmesi, (ii) deneyim bilgisinin kaydedilmesi, (iii) kaydedilen deneyim bilgisinin yeniden yorumlanması (iv) 2 ve 3 boyutlu deneyim haritaları oluşturulması aşamalarını kapsamıştır (Tablo 1). Belirlenen çaış̧ma alanının önceden tanımlanmış 2 temel kavram odağında -geçiş ve iz-- ve 3 duyusal olgu çerçevesinde --koku, ses ve doku-- deneyimlenmesi, mekânsal özelliklerin bu filtreler ışığında gözlemleme, duyumsama, algılama yoluyla analiz edilerek deneyim bilgisinin elde edilmesi hedeflenmiştir. Yer, bu filtreler aracılığıyla deneyimlenmiş ve deneyim bilgisi fotoğraf, video, ses kaydı, mülakat, eskiz ve harita okuma gibi çeşitli araçlar kullanılarak kayıt altına alınmıştır. Kaydedilen kentsel mekân katmanları daha sonra yeniden yorumlanmış, deneyim bilgisi 2 ve 3 boyutlu temsil araçları kullanarak poster ve maket aracılığıyla yorumlanmıştr.

Bu yöntemsel çerçevede Vefa-Zeyrek-Fener-Balat semtlerini kapsayan çalışma alanında bir mekânsal deneyim
Tablo 2. Yere ait deneyim bilgisinin ele alınacağı lensler

\begin{tabular}{|c|c|c|c|c|c|}
\hline \multicolumn{3}{|c|}{ Grup A: 'geçiş̧' } & \multicolumn{3}{|c|}{ Grup B: 'iz' } \\
\hline Grup A1 & Grup A2 & Grup A3 & Grup B1 & Grup B2 & Grup B3 \\
\hline 'koku' & 'ses' & & 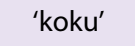 & & \\
\hline $\begin{array}{l}\text { odağında } \\
\text { analiz }\end{array}$ & $\begin{array}{l}\text { odağında } \\
\text { analiz }\end{array}$ & $\begin{array}{c}\text { odağında } \\
\text { analiz }\end{array}$ & $\begin{array}{l}\text { odağında } \\
\text { analiz }\end{array}$ & $\begin{array}{c}\text { odağında } \\
\text { analiz }\end{array}$ & $\begin{array}{c}\text { odağında } \\
\text { analiz }\end{array}$ \\
\hline
\end{tabular}

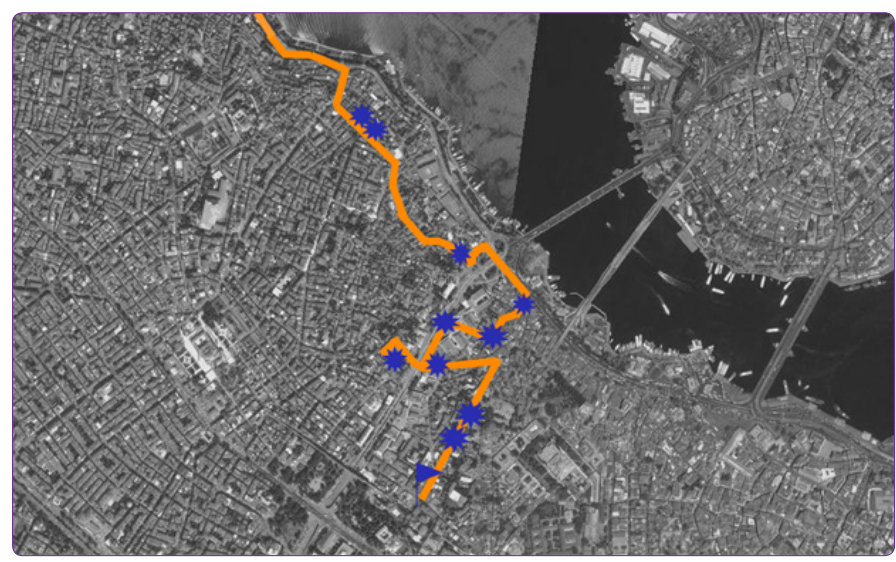

Şekil 4. Mekânsal deneyim güzergahı.

güzergâhı belirlenmiştir; tarihi Vefa Bozacısı güzergâhın başlangıç noktasını, Sveti Stefan Bulgar Ortodoks Kilisesi ise bitiş noktasını oluşturmuştur (Şekil 4). ${ }^{2}$ Öğrenciler bu başlangıç ve bitiş noktaları arasında önceden belirlenen önemli yapıları deneyimleyecek şekilde kendi güzergâhlarını belirlemede özgür bırakılmıştı. ${ }^{3}$ Böylece kişisel deneyimin çeşitliliğinin ve rastlantısallığının ortaya çıkarılması hedeflenmiştir.

Alan çalışmasına ve verilerin toplanmasına dayanan çalıştayın ilk gününde yürütücüler ve öğrencilerin Vefa Bozacısı'nda buluşmasının ardından, katlımcı öğrenciler 'geçiş' ve 'iz' kavramları odağında 2 büyük gruba ayrılmışlardır (Tablo 2). Daha sonra her bir grup kendi içinde 'koku', 'ses' ve 'doku' temaları odağında 3'er alt gruba ayrılarak mekân deneyimlerinde bu filtreleri gözetmeleri beklenmiştir. Gruplara ayrılan öğrenciler güzergâh boyunca farkIı mekânları ses, koku ve doku olarak belirlenen duyusal filtreler aracılığıyla deneyimlemiş, farklı sesleri, kokuları ve dokuları fotoğraflama, video ve ses kayıtları ve eskiz çizimi gibi araçlar kullanarak belgelemiş ve böylece deneyim bil-

\footnotetext{
Vefa Bozacısı bir asırı aşkın süredir aynı aile tarafindan aynı mekânda işletilen bir mekân olması bakımından çalıştayın odağındaki iz ve geçiş kavramlarının hem fiziksel hem de belleğe ait katmanlar çerçevesinde irdelenebilme potansiyeli sunmuştur. Sveti Stefan Bulgar Ortodoks Kilisesi çalışma alanını denizle temas ederek sonlandıran bir bitiş noktası olarak belirlenmiştir.

3 Öğrencilerin deneyimlemesi gereken diğer noktalar Molla Zeyrek Camii (Pantokrator Manastırı), Atıf Efendi Kütüphanesi, Sarı Beyazıt Caddesi, Kasnakçılar Sokak, Hacı Kadın Caddesi, İşlek Sokak, Yeni Hayat, Elvanzade Cami sokak, Molla Hüsrev Camii (Küçük Mustafa Paşa Mah.), Küçük Mustafa Paşa Caddesi, Baki Dede Sokak, İstanbul Manifaturacılar ÇarşıSı (IMÇ) ve Kadir Has Caddesi olarak belirlenmiştir.
} 

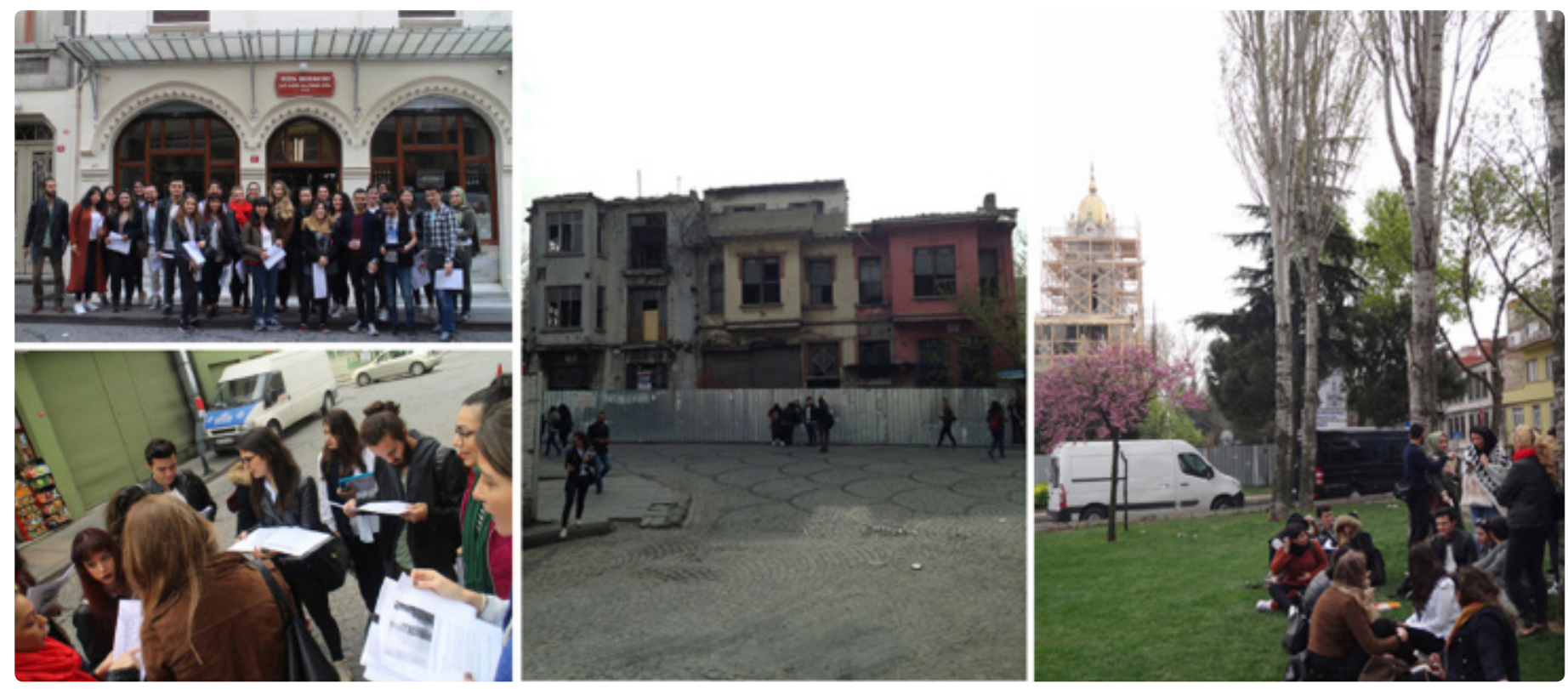

Şekil 5. Alan araştırmasının aşamaları.

gisini kayıt altına almışlardır (Şekil 5). Alan çalışmasında, gözlemleme eyleminin getirdiği mesafe ve dolaylı ilişkinin, duyumsama ve algılama eylemleri odağında beden-öznelerle yer arasında dolaysız ve fiziksel bir etkileşime dönüşmesi hedeflenmiştir (Şekil 6a-c).

Çalıştayın birinci günündeki alan araştırması, "kent mekânının katmanları" konulu bir sunumla desteklenmiş ve öğrencilerin bir kenti oluşturan fiziksel yapılanmaların ötesine bakarak düşünmeleri ve tartışmaları teşvik edilerek bu deneyimi nasıl edinebilecekleri üzerine tartışımıştır. Çalıştayın ikinci gününde alan araştırmasında toplanan veriler stüdyo ortamında yaparak öğrenemeye dayalı uygulamalar aracılığıyla irdelenmiştir. Bu uygulamalar çalışma alanındaki görünür ve görünür olmayan katmanlara dair (i) analiz, (ii) yeniden yorumlama (iii) duyusal deneyimin karşılığı olacak fiziksel malzemelerin belirlenmesi ve dönüştürülmesi, (iv) dönüştürülen malzemelerle birim tasarımı aracılığıyla yere dair duyusal deneyim bilgisinin yeniden haritalanması aşamalarını kapsamıştır.

Arazide kaydedilen deneyim bilgisi öncelikle 2 boyutlu temsil araçları kullanılarak ortaya koyulmuştur. Bu süreç grupların 1/1000 hâlihazır harita üzerine kendi güzergâhlarını farklı renkler kullanarak aktarmasıyla başlamıştır (Şekil 7). Böylece her grubun farklı filtreler aracılığıyla gerçekleştirdikleri mekânsal deneyimlere dair örtüşmeler ve farklılaşmalar açığa çıkarılmıştır (Şekil 8a, b). Çalışma grupları haritaya ayrıca kendi filtreleri ışığında fotoğraflarını çekerek kaydettikleri koku, ses ve doku kaynaklarını ilgili yerlere eklemişlerdir. Kaydedilen duyusal kaynaklarının yerleri imge-resimler (pictograms) kullanılarak harita üzerine işaretlemiştir. Mekâna dair imgelenme, her çalışma grubunun bilgi topladıkları ol-
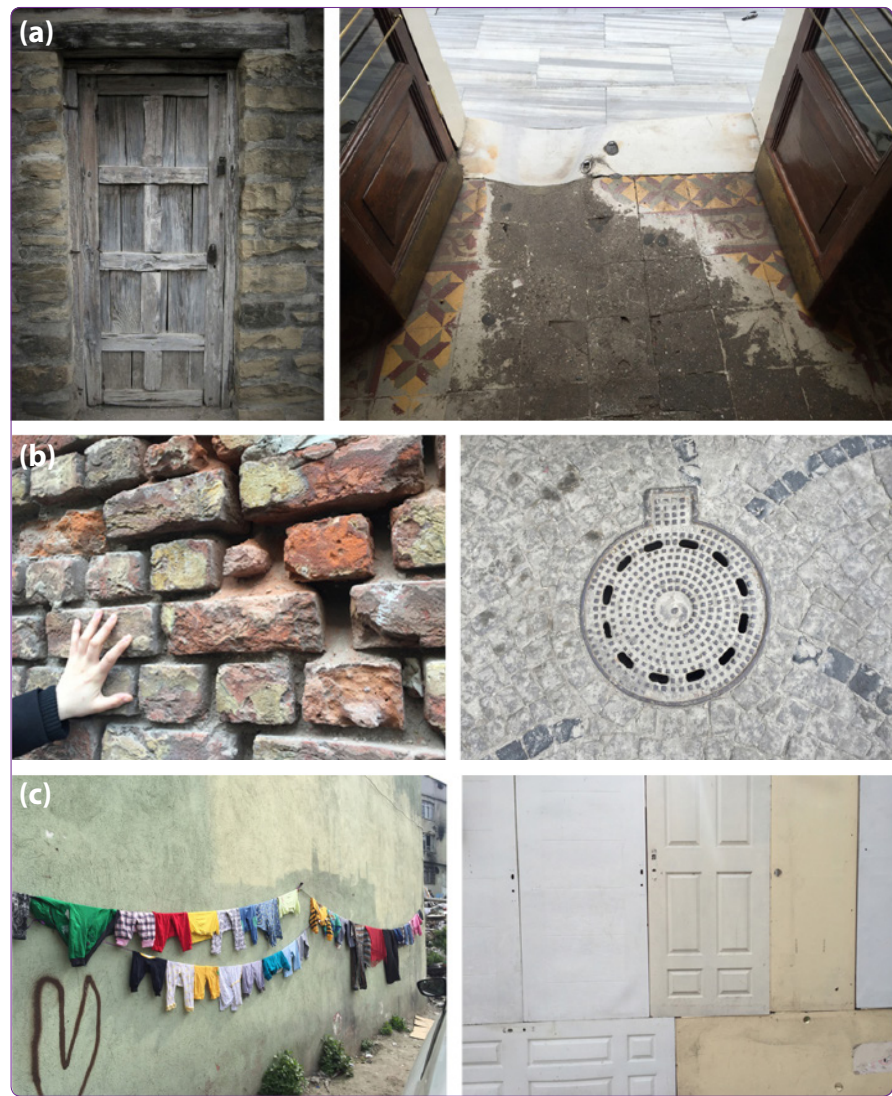

Şekil 6. (a) İz ve geçiş kavramlarına dayalı deneyim bilgisi. (b) Doku olgusuna dayalı deneyim bilgisi. (c) İz ve geçiş kavramlarına dayalı deneyim bilgisi.

gusal kaynaklara dair oluşturdukları lejantlar aracılığıyla sağlanmıştır. Böylece çalıştay katılımcılarının belirlenen güzergâhta edindikleri deneyim bilgisinin kaynaklarına dair katmanlar 2 ve 3 boyutlu araçlar yardımıyla görünür hale getirilmiştir. 


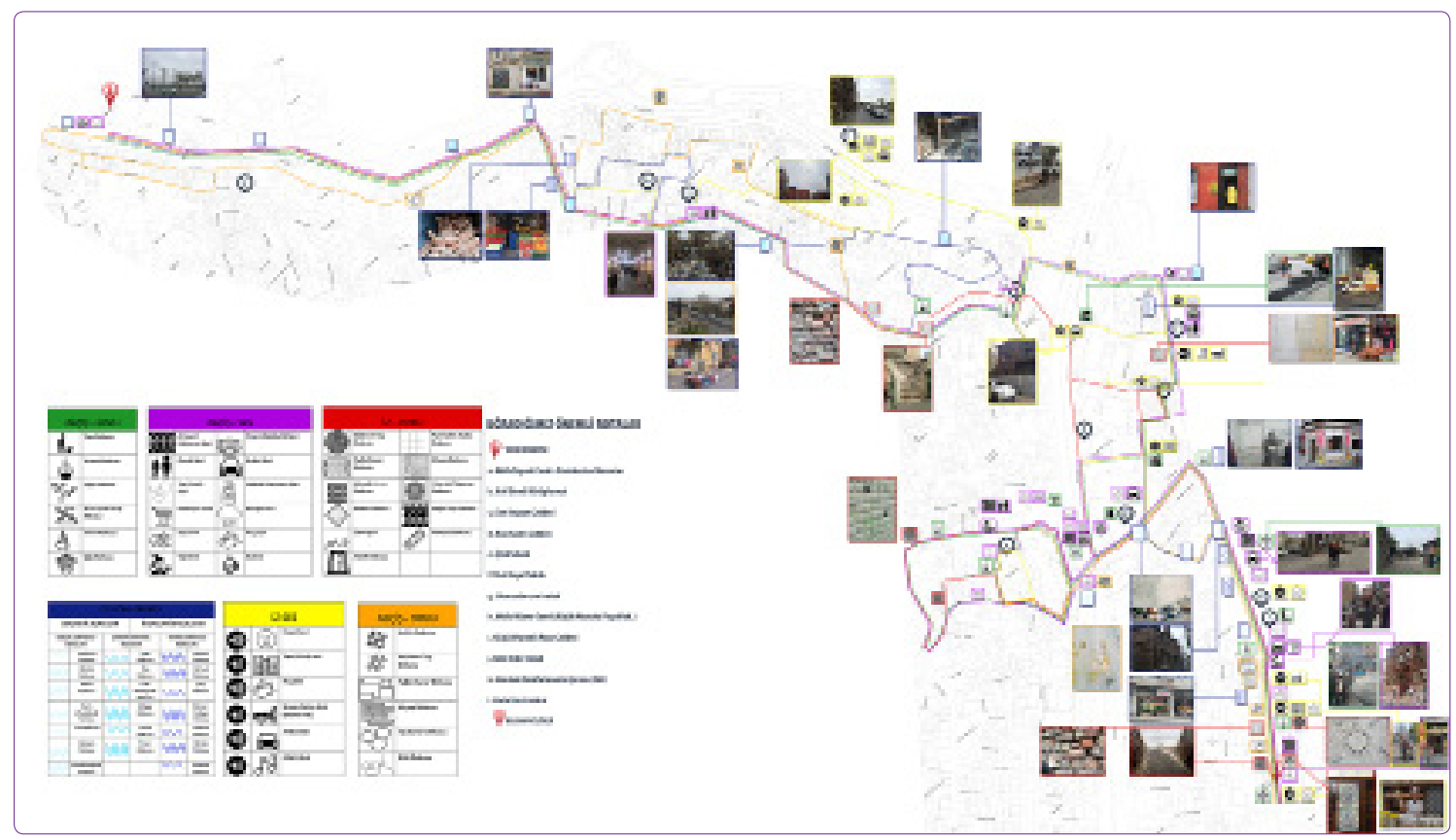

Şekil 7. İki boyutlu deneyim haritası.

\section{Deneyimsel Haritalama}

Çalışmanın kapsamına uygun olarak seçilen yöntem deneyimsel haritalama yöntemidir. Geleneksel haritalardan farklılaşan bu yöntem, mekânsal deneyim güzergâhı boyunca beden-öznelerin karşılaşttkları deneyim kaynaklarını, bu kaynakların güzergâha referansla konumlarını, fotoğraflarını veya eskizlerini içermektedir. Deneyimsel haritalama yöntemi yerin deneyime dayalı bilgisinin, kayde-
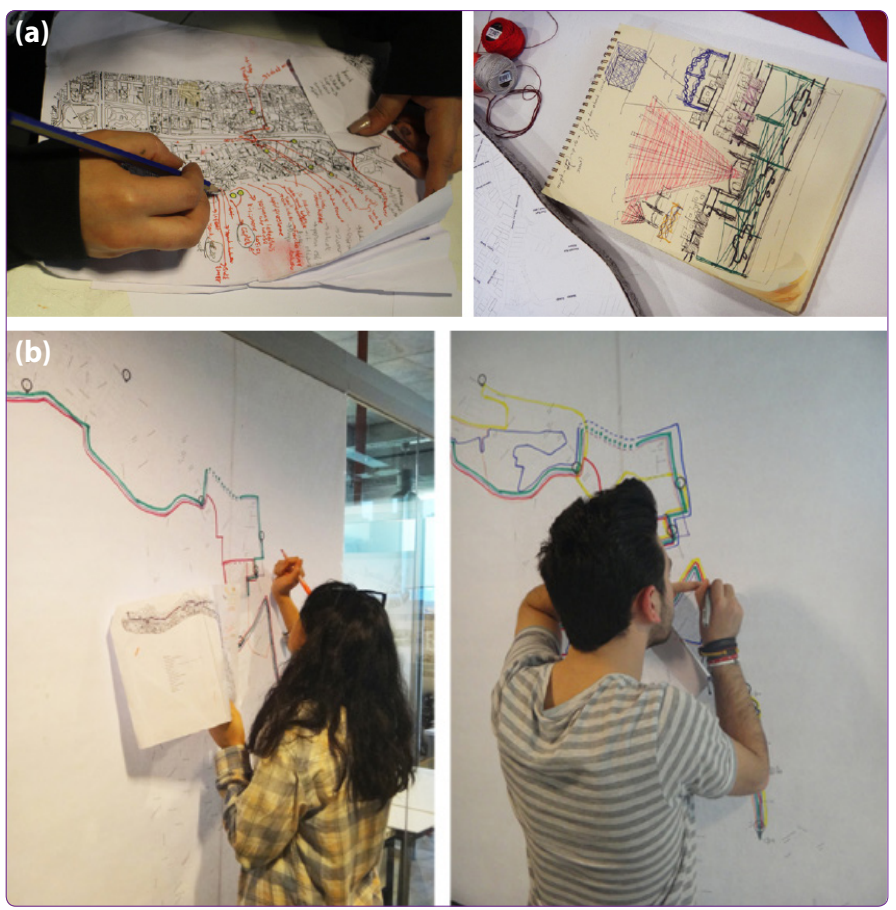

Şekil 8. (a) Yer bilgisinin analizleri. (b) Yer bilgisinin 2 boyutlu deneyim haritasına aktarılması. dilen kentsel mekânın bilgi katmanlarının görünür kılındığı daha büyük bir bağlama oturtulmasına olanak tanımaktadır. Deneyimsel haritalama yönteminin üç önemli unsuruna dikkat çekilebilir; (1) durumsallık (situational), (2) değişkenlik (dynamism), (3) öyküsellik (narration) (Şekil 9). Deneyimsel haritalar durumsaldır; çünkü beden-öznelerin belli bir zaman aralığında belli bir mekândaki deneyimlerini yansıttr; anlık ve şimdiye ait deneyimleri temsil eder. Deneyimsel haritalar beden-öznelerin mekândaki hareketi deneyimlerinin ve dolayısıyla elde edilen mekânsal bilginin sürekli değişmesine bağlı olarak aynı zamanda dinamik bir yapıdadır, değişkendir. Beden-özneler mekânı hareket eylemi içinde algılarlar. Hareket olgusunun getirdiği akışkan mekân deneyimi, kentsel mekânda ana akslar ya da anıtlar gibi ilk bakışta algılanan olguların ötesine geçebilmeyi, beklenmeyen, şaşırtıcı, hatta kimi zaman örtük olan olgularla yüz yüze gelmeyi ve onları deneyimleyebilmeyi tetikler (Gibbons, 2007). Bu durum beden-özneyi kentsel

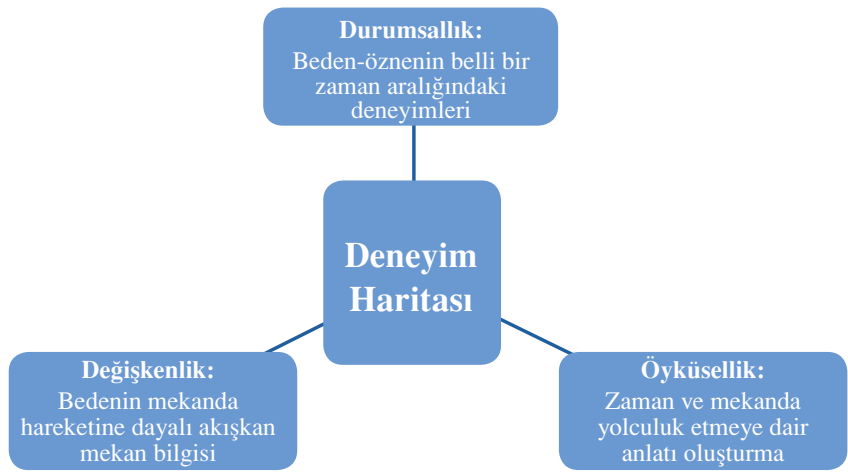

Şekil 9. Deneyim haritası. 
mekân deneyiminin odağına oturturken, onları aynı zamanda De Certeau'nun (1988) dikkat çektiği gibi "kentin gerçekleştiricileri" (actualisers of the city) kılmaktadır. De Certeau'ya (1988, s. 91-110) göre kentin kendisinden çok, kentte seyahat eden, kentle etkileşimde bulunan kentliler birer bilgi kaynağıdırlar; bu bilgi ise özneldir ve deneyimseldir. Mekânda ve zamanda deneyim eylemini gerçekleştiren beden-özneler, kendi yer bilgisi repertuvarlarını oluştururlar.

Çalıştayın ikinci gününde çalışma grupları, 'iz' ve 'geçiş' kavramları temelinde farklı duyusal filtreler aracılığıyla topladıkları deneyim bilgisini 3 boyutlu bir deneyim haritasına dönüştürmüştür. Deneyim haritası aracılığıyla, kent mekânında görünür olmayan, algıya dayalı niceliklerin kendi içlerinde ayrıştırılması ve bunların oluşturduğu çok katmanlılığın görünür olacak şekilde tasarlanması amaçlanmıştr. Öğrencilerin çalışma alanında bedenleriyle deneyimledikleri, duyusal yolla algılanan mekânsal olguların nitelikleri analiz edilerek, bu nitelikleri en iyi şekilde temsil edilebilecekleri malzemeler seçilmiş ve bu malzemeler deneyimin doğasına uygun olacak şekilde çeşitli yöntemler kullanılarak dönüştürülmüştür. Daha sonra bu mekânsal olguların konumuna ve yoğunluğuna bağlı olarak 3 . boyutta farklı katmanları görünür kılan tasarımlara gidilmiştir. Bu sürecin aşamaları (i) görünür olan ve görünür olmayan deneyim bilgisinin biçime dönüşmesi (ii) mekânsal bilginin yeniden kodlanması aracılığıyla bu biçimlerin bir gramer oluşturması, (iii) birim tasarımları ve birimlerin tekrarına dayalı katmanların meydana getirilmesi şeklinde özetlenebilir (Şekil 10a-c).
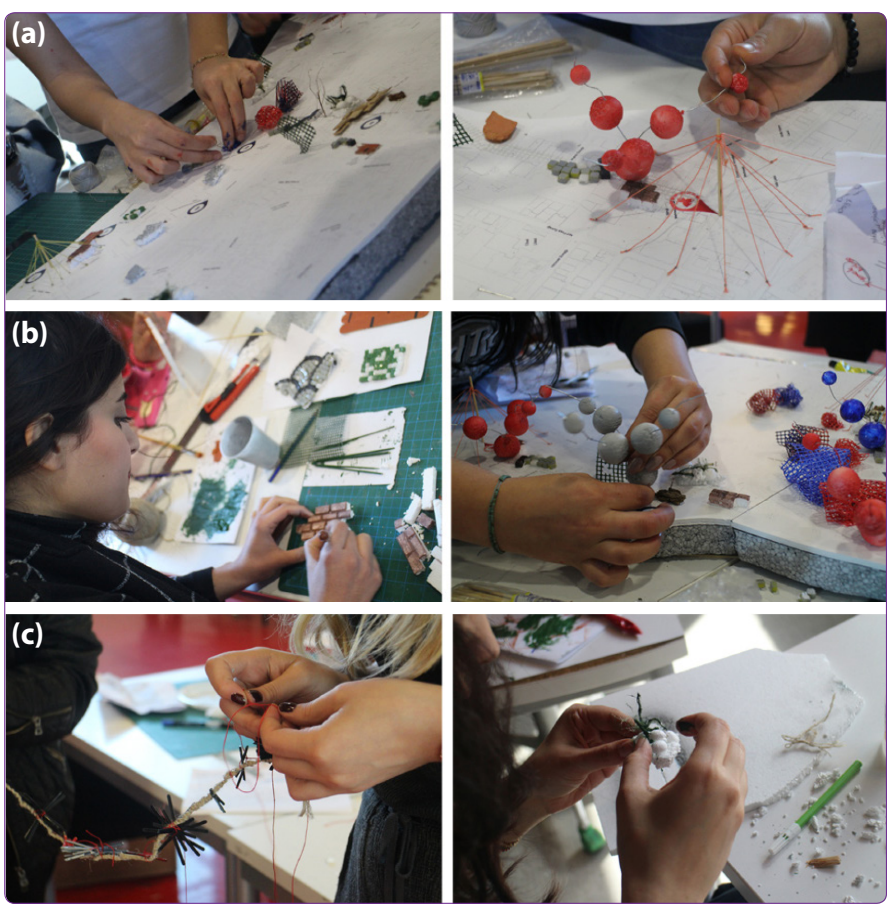

Şekil 10. (a-c) Deneyim bilgisinin 3 boyutlu temsil aşamaları.
Deneyim haritalarının en önemli katkısı, kentsel mekânın çok boyutluluğunu görünür kılmak üzere yaparak oluşturulmaları ve aktif bir yapıda olmalarıdır. Ele alınan fiziksel alana dair "karmaşık, dinamik, çok sesli bulguları temsil etme ve aynı zamanda çok sayıda hikâyeyi, yer duygusunu, hatıraları ve anlamları (geçmişe ve şimdiye ait) belli ve konumlandırılmış coğrafi bir alanla bütünleştirme" potansiyeline sahiptirler (De Nardi, 2014, s. 5). Deneyim haritaları hem yer bilgisinin kayıt altına alınması hem de temsil edilmesi aşamalarında yorumsal bir süzgeçten geçer; bu yönüyle de bir "anlatıya" (narrative) dayandığı söylenebilir. Bu, zaman ve mekânda yolculuk etmeye dayalı bir anlatıdır, çok seslidir, fiziksel olgularla olduğu kadar hatıra, korku, heyecan, merak, bağlılık, yabancılaşma gibi soyut kavramlarla da ilişkilendirilebilir (De Nardi, 2014, s. 5-22). Böylece, gözle görülür elle tutulur unsurların yanında görünür olmayan, yaşanmışlıklar yoluyla ya da biraz hayal gücü ve merakla görünür hale getirilebilen unsurların bütününden oluşur.

\section{Bulgular ve Tartışma}

Çalıştayın bulguları, benimsenen fenomenolojik yöntemsel yaklaşımı destekler nitelikte olmuştur. Kullanılan deneyimsel haritalama yöntemi neticesinde, yer ve mekân bilgisi yeri deneyimleyen beden-özneler tarafindan kurgulanmıs ve bu bilginin temsil edilme araçları tasarlanmıştır. Beden-öznelerin bireysel olarak edindiği ve kaydettiği beneyim bilgisi, daha sonra grup çalışması aracılığıyla üretilen bir tasarım bilgisine dönüştürülmüştür. Bu tasarım bilgisi kent katmanlarının üst üste geldiği ve/veya iç içe geçtiği bir örüntüyle oluşturulan 3 boyutlu deneyimsel haritada ifade bulmuştur.

Çalıştayın bulgularını (1) katılımcı öğrenciler ve yürütücüler ve (2) süreç bağlamında değerlendirmek mümkündür. Katılımcı öğrenciler için bu çalıştay, mimarlık eğitiminin bir parçası olan 'alan araştırmalarına' yeni bir bakış açısı geliştirmelerine katkı sağlamıştır. Bu yeni bakış açısı, öncelikle kendilerini fiziksel mekâna birer beden-özne olarak yeniden konumlandırmalarını, kentsel mekâna bedensel duyuları aracılığıyla yaklaşmalarını destekleyen bir katkı sağlanmıştır. Mekânı, bekli de daha önce hiç ele almadıkları yönleriyle, barındırdığı görünür olan ve olmayan unsurları irdelemelerini; sadece görerek değil, aynı zamanda duyarak, dokunarak, işiterek deneyimleme ve algılama, kültürel ve tarihi çağrışımları canlandırma yoluna gitmelerini sağlamıştır. Böylece beden ve yer arasında dolaysız ve derinlemesine bir etkileşim oluşmuş ve yere dair bilgi bu etkileşim üzerinden, tanımlanan kavramsal ve olgusal filtreler (geçiş, iz, koku, ses, doku) aracılığıyla kaydedilmiş, yorumlanmış ve yeniden üretilmiştir. Öğrencilerin kendi bedenlerine dair farkındalıkları artmış, bedensel duyularının aktive olma biçimleri de farklııı göstermiştir; örneğin bir öğrencinin taş bir duvara dokunarak onun dokusunu 
algılamaya çalışması, bir diğerinin geçtiği sokakta bulunan görsel uyaranlardan kendini soyutlayıp sadece farklı ses kaynaklarına odaklanması gibi.

Öğrenciler açısından çalıştayın zorlayıcı kısımlarından biri, deneyimin öznelliği-çeşitliliği ile deneyim bilgisinin kolektif temsili arasında denge arayışı olmuştur. Alan çaıışması sırasında bireysel olarak belirledikleri rotalarda her beden-özne farklı olgusal kaynaklara yönelmiş, onlar için önemli olan bilgiyi kaydetmiş, daha sonra stüdyo ortamında kaydedilmiş yer bilgisini gruplar halinde ele alıp yorumlamışlardır. Bu noktada yaparak öğrenme ve birbirinden öğrenme eğitsel kazanımlarının gerçekleştiği gözlemlenmiştir. Öğrenciler açısından çalıştayın ikinci zorlayıcı kısmı, beden-özne olarak deneyimledikleri ve kaydettikleri yer bilgisinin temsili aşaması olmuştur. Bu temsil biçimi, kentsel mekâna dair görünür olan ve görünür olmayan unsurların niteliksel ve niceliksel özelliklerini, örneğin kokunun uçucu ve geçirgen olması, ses kaynağının noktasallığı ve kaynağından çıktıktan sonraki uzamsal yayılımı gibi nitelikleri, en iyi yansıtacak malzemelerin seçilmesi, malzemelerin yapısal olarak dönüştürülmesi, her bir olgusal kaynak için bir birim tasarlanması ve daha sonra bu birimlerden oluşan katmanların ve katmanların bir araya gelmesinden örüntülerin oluşturulmasını içermiştir. Malzemenin görsel ve dokunsal özellikleri kadar strüktürel yapısının da irdelendiği birim tasarımı sürecini, bu birimlerin alan haritasının oluşturduğu altlıktaki organizasyonunun tasarlanması izlemiştir. Bu organizasyonda çalışma alanındaki duyusal kaynakların konumlanışı, yoğunlaşıp seyreldiği noktalar, örtüşme-kesişme-ayrışma biçimleri irdelenirken, kent mekânının katmanları 3 boyutlu olarak görünür hale getirilmiştir (Şekil 11).

Öğrenciler geleneksel temsil araçlarını, malzemenin dönüştürülmesi için geleneksel olmayan şekillerde kullanmışlar, böylece yeni temsil araçları geliştirmişlerdir. Bu yeni temsil araçları her bir alt grup için özgünlük göstermiş ve kendi içinde bir bütünsellik arayışına temellenmiştir. Bunun yanında, tıpkı kent mekânının çok katmanlıı̆̆ı gibi, farklı alt grupların temsillerinin birbiriyle kuracağı 3 boyutlu ilişkinin tasarlanması önem kazanmıştır. Birimlerin organizasyonu ve farklı organizasyonların üst üste, yan yana gelerek ya da iç içe geçerek oluşturulan örüntü aracılığıyla, kentsel mekândaki katmanlaşma temsil edilmiştir. Dolayısıyla öğrenciler sadece tasarlama bilgisiyle değil aynı zamanda yöntem bilgisi üzerinde çalışmışladır. Bu yöntem bilgisi bedensel deneyim aracılığıyla edinilen yere ait deneyim bilgisinin 2 ve 3 boyutlu temsil araçlarıyla ifade bulmasına dayandırılmıştır. Yöntem bilgisi öğrenciler için bir öğrenme deneyimini beraberinde getirmiştir.

Sezgisel ve deneysel olarak gelişen tasarım sürecinde, çalıştay yürütücüleri bir adım geri çekilerek süreci öğrencilerin yönlendirmesine olanak tanımıştır. Çalıştay yürütü-
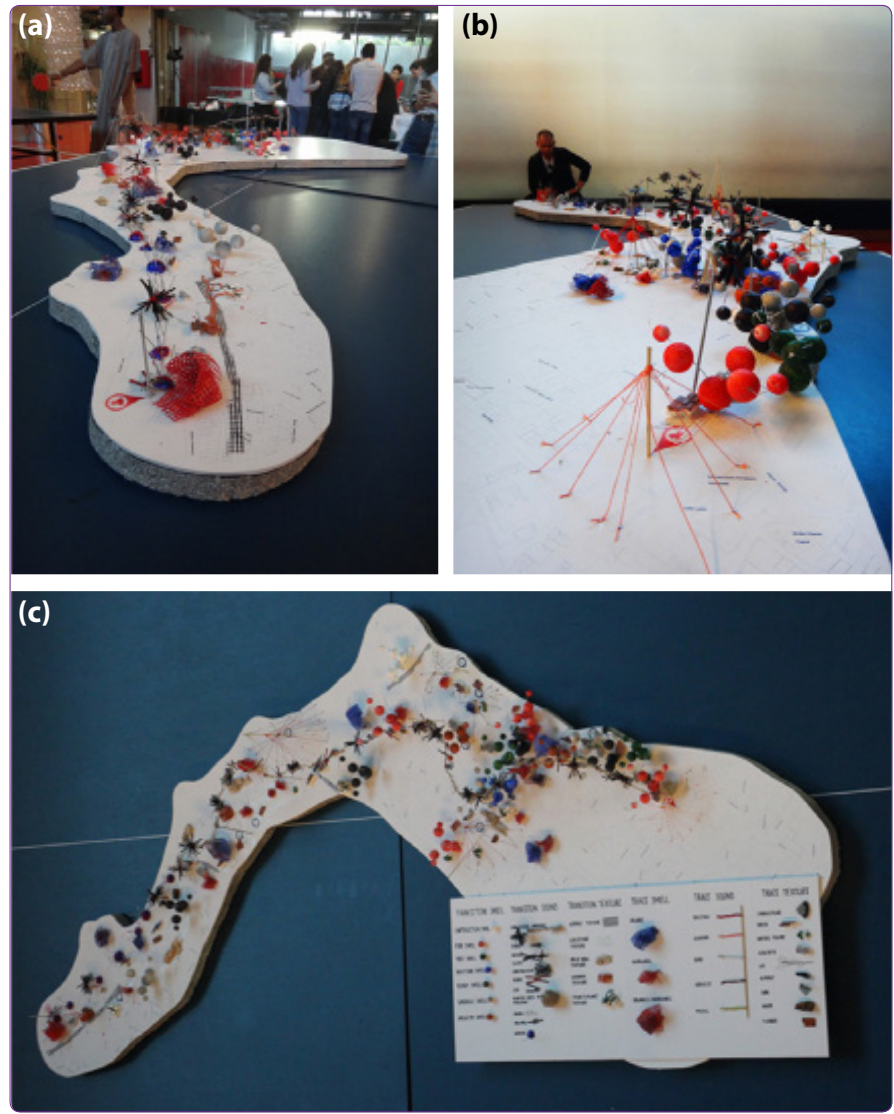

Şekil 11. (a-c) Üç boyutlu deneyim haritası.

cüsü, öğrencinin yönlendirilmeye ihtiyaç duyduğu anlarda devreye girmiştir. Öğrenci-yürütücü-süreç-ürün arasında döngüsel bir etkileşim mevcuttur. Bireylerin deneyimi sürecin akışını --biraz da sezgisel olarak-- etkilemiş, süreç tasarımı da sonuç ürünü şekillendirmiştir. Çalıştayda deneyimsel haritalama yöntemiyle oluşturulan 3 boyutlu maket sonuç ürünü oluşturmuştur. Ancak sonuç ürün kadar sürecin de bir ürün olarak değerlendirilmesi mümkündür. Süreç, çalıştayın alan çalışması ve stüdyoda yaparak öğrenmeyi içeren 2 günlük aktiviteleri kadar, sonrasında yürütücü ve öğrencilerin kendi deneyimlerini anlatarak bir diyalog ortamı oluşturdukları değerlendirme buluşmasını da kapsamıştır (Şekil 12). Gruplar çalışmalarının düşünsel arka planını, süreci ve deneyim haritasına yaptıkları katkıları sözlü anlatım ve görsel/işitsel sunum aracılığıyla hem diğer gruplar hem de üniversitedeki diğer öğrenciler ve öğretim elemanlarıyla paylaşmışlardır. Benzer şekilde çaIıştay yürütücüleri de çalıştayın amacı ve kapsamını, gerçekleştirilen aktiviteleri ve sonuç ürün olarak tasarlanan ve üretilen deneyim haritasını kendi deneyimleri odağında irdelemişler ve izleyicilerle paylaşmışlardır. Böylece öğrenci ve yürütücülerin kendi çalıştay deneyimlerini paylaştıkları diyalog ortamı, yeni bir deneyimsel süreç doğurmuştur. Bu noktanın, tasarımın döngüsel yapısına işaret etmekte olduğu söylenebilir: tasarım sürecinin maket, çizim gibi salt sonuç ürün üzerinden okunabileceği gibi, aslında sürecin 


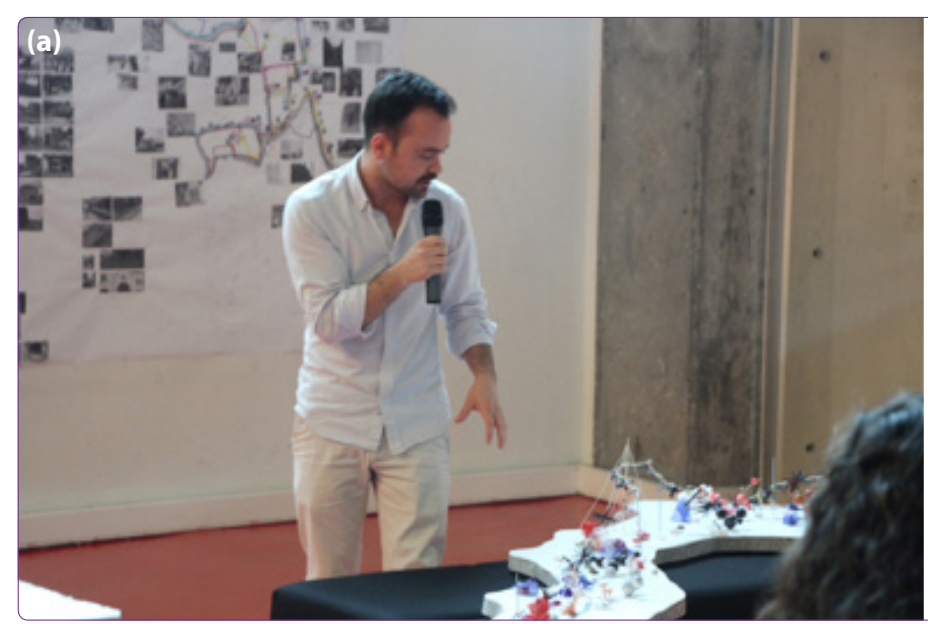

Şekil 12. (a, b) Çalıştay sunumları.

tasarımının kendisinin de bir ürün olarak değerlendirilebileceğini göstermektedir. Öğrenme, tasarım eylemi, süreç ve ürün arasındaki döngüsel etkileşimden doğmaktadır.

\section{Sonuç}

Bu çalışmada mimarlık eğitiminin okul mekânını aşarak gerçek hayata dokunmasını, öğrencilerin yer ile, kent ile, beden ile etkileşimlerinin artırılması amacıyla, yerin beden üzerinden deneyimlenmesi ve deneyimsel bilginin yeniden üretilmesi için bir yöntem olarak deneyimsel haritalama yönteminin irdelendiği bir çalıştayın kavramsal çerçevesi, süreci ve bulgularını tartş̧ılmıştı. Çalışmaya konu olan çalıştay aracılığıyla, beden-öznelerin mekânla ve kentle 'bedensel deneyim' odağında kurdukları temas bir tasarım araştırmasına dönüşmüştür. Bu çerçevede elde edilen pedagojik kazanımlar başlıca 3 temel başlıkta ele almak mümkündür:

(1) bilgiye ulaşmanın yollarının araştırılması

(2) bilgiyi ayrışttrma, dönüştürme ve yeniden üretme stratejilerinin geliştirilmesi

(3) süreç tasarımı ile ürün tasarımının iç içe geçtiği bir deneyim sunması

Illk olarak çalıştaya katılan öğrenciler belli bir mekânsal/ zamansal bağlam odağında farklı görme, düşünme ve bilgiye ulaşma yollarını araştırmışlardır. Yer bilgisi bedenöznelerin kentsel mekânla etkileşim ortamında ve çoğul okumalar çerçevesinde keşfedilmiştir. Yere deneyimsel olarak bağlanmış beden-özneler görünür olan ve görünür olmayan bilgi katmanlarını incelemiş, kaydetmiş ve kavramsallaştırarak kendi öznel süzgeçlerinden geçirmişlerdir. Böylece beden-özneler mekânla karşılaşmalarında her karşılaşmanın durumsallığından doğan potansiyellere ilişkin farkındalık kazanmışlardır. Bu yaklaşımın izlerini sonuç üründe de görmek mümkündür; tek bir deneyim haritası üzerinde, katılımcı beden-öznelerin deneyimleri aktarılmış ve farklı durumsallıkların kesişmesi, çakışması, ayrışması

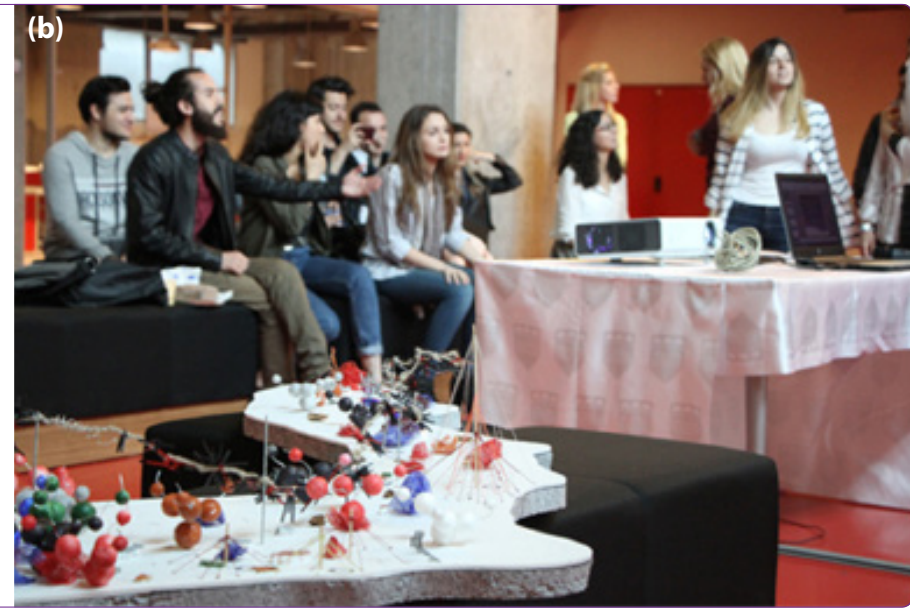

sonucunda yatay ve düşeyde ilişkilenen katmanları meydana getirmiştir. Diğer bir deyişle, deneyimsel haritalama stratejisi çoklu beden, çoklu algı ve çoklu mekânsalığın çok katmanlı bir temsil aracı olmuştur. Deneyimsel haritalama, çalıştayın kavramsal çerçevesiyle ilişkili olarak, öğrenciler için farklı mekânsal deneyimlerin tekil fiziksel temsilinin ötesinde çok yönlü örüntüsel ilişkilerini keşfetmeyi ve anlamlı bir bütünsellik arayışını tetiklemiştir.

íkinci olarak çalıştaya katılan öğrenciler bedensel deyimleri aracılığıyla ulaşttkları ve kaydettikleri deneyimsel bilgiyi bozup, dönüştürüp yeniden üretmişler ve bunu yaparken de bilginin somutlaştırılmasını amaçlayan alternatif temsil araçları tasarlamışlar, yeni problem çözme becerileri geliştirmişlerdir. Beden- özneler bir yandan kendi mekânsal deneyimleri üzerinden yer bilgisi repertuvarı geliştirirken, bu repertuar farklı beden-öznelerin repertuvarlarıyla birleşip katmanlaşmıştır. Deneyimin öznelliği ve çeşitliliği ile deneyim bilgisinin kolektif temsili arasında bir denge yakalamaya çalışan öğrenciler, mekân bilgisinin yeniden üretimi için bütüncül stratejiler geliştirmişlerdir. Bu yönüyle çalışmanın, beden-öznelerin "duruma göre farklılık gösteren ve rastlantilara izin veren taktikler" geliştirmelerine katkıda bulunduğu söylenebilir (Aydınlı \& Kürtüncü, 2014). Bu durumsallık, öğrencilerin alan araştırmasındaki mekân deneyimlerinde olduğu kadar, mekânsal deneyim bilgisinin bozulup, analiz edilip, dönüştürülüp yeniden üretildiği stüdyo deneyiminde de kendini göstermiştir. Çalışma grupları yapma eylemi temelinde kendi mekân bilgisi repertuvarlarına özgü tasarım ve temsil araçlarını geliştirmişlerdir. Bizzat stüdyoda üretim yapılmasıyla gelişen bir keşif süreci söz konusudur; bu keşif süreci hayal gücüne, rastlantısallığa, deneyselliğe ve yaparken gelişen ürün üzerine düşünmeye olanak vermiştir.

Üçüncü olarak çalıştayın yöntemsel yaklaşımının temellendiği deneyimsel haritalama yöntemi salt bir ürün ortaya çıkarmayı değil, ürünü kolektif olarak tasarlama sürecinin de katılımcı öğrenciler tarafindan tasarlanmasını teşvik et- 
miştir. Deneyimsel haritalama, bir yandan kentsel mekânın çok boyutlu ve bedensel duyuları aktive eden yapısını temsil etmeyi mümkün kılarken, bir yandan da aynı bedensel deneyimin özgünlüğü, durumsallığı ve zamansallığı gibi bu temsilde de farklı anlayışlara ve yorumlamalara yer verilmesini mümkün kılmıştır. Çeşitli duyusal filtreler aracılığıyla kent mekânını deneyimleyip deneyimsel bilginin analiz edilmesinden sonra, bu çok katmanlı bilginin tasarlanan alternatif temsil araçlarıyla dönüştürülerek, yeniden üretilerek bir gramere/matematiğe dönüştürülmesi çalıştayın süreç tasarımı kısmını oluşturmuştur. Yeniden üretilerek temsil edilen deneyimsel bilginin 2 ve 3 boyutlu olarak görselleştirilmesi çalıştay sonunda elde edilen bir sonuç ürün olarak karşımıza çıkmaktadır.

Fiziki mekânın çok boyutluluğunun bedensel deneyimler aracılığıyla algılanması, mimarlığın maddesel gerçekliğini ve zamansalığını, zaman içindeki başkalaşımını/sürekliğini keşfedebilmeyi sağlamaktadır. Bu çalıştayın temel kazanımı bedensel deneyimin bir bilgi kaynağı olarak yeniden keşfedilmesi; mekân bilgisinin aynı zamanda bir tasarım-temsil-üretim bilgisi olarak ele alınması olarak tanımlanabilir. Çalıştay aracılığıyla bedensel deneyime dayalı mekân bilgisinin çok katmanlı ve ilişkisel bir yapıya sahip olduğuna dair farkındalıkları artmıştır. Aravot $(2008$, s. 10) fenomenolojinin mimarlık eğitimi için bir yöntem olarak taşıdığı potansiyellere vurgu yapmakta, bu potansiyelleri hali hazırda mimarlık eğitiminin doğası gereği bağlı olduğu "ilk elden kişinin kendi bakış açısından doğan bilinçli deneyim"le ilişkilendirmektedir. Bu çalışma öğrencilerin birer özne olarak ve birebir çevreleriyle, mekânla etkileşim içinde araştrarak, farkındalık ve deneyim kazanarak kendini gerçekleştirme süreçlerinin desteklenmesine katkı sağlamıştır.

\section{Teşekkür}

2-3 Nisan 2016 tarihlerinde İstanbul Kemerburgaz (Altınbaş) Üniversitesi Mimarlık Bölümü ve İç Mimarlık ve Çevre Tasarımı Bölümü öğrencilerinin katlımıyla gerçekleştirilen "Re-Mapping the Visibles and Invisibles of Vefa-Zeyrek-Fener-Balat" isimli çalıştayın koordinatörleri Merve Aşçıoğlu, M. Aygün Aşık, H. Büşra Başkurt ve Gülce Kırdar'a ve kattlımcı öğrencilere değerli katkıları için teşekkür ederiz.

\section{Kaynaklar}

Aravot, I. (2008) "Phenomenology as Architectural Method", Ed.: I. Aravot, E. Neuman (editor) Invitation to ArchiPhen Some Approaches and Interpretations of Phenomenology in Architecture, The Center for Architectural Research and Development Technion.

Aydınlı, S. (2008) “Mekân'dan Mekânsal'a: Mekânın Zamansallığı/Zamanın Mekânsallığı”, Ed.: A. Şentürer, Ş. Ural, Ö. Berber, F. Uz Sönmez (editörler) Zaman-Mekân, Çev.: E. Orman, İstanbul, YEM Yayın, s.150-161.

Aydınlı, S. \& Kürtüncü, B. (2014) Paralaks Oda. İstanbul: Cenkler Matbaacılık.

Çalak, I. E. (2013). "Formation Process of Memory Through Ur- ban Space and Architecture", Basılmamış Doktora Tezi, Mimar Sinan Güzel Sanatlar Üniversitesi, Fen Bilimleri Enstitüsü, Mimari Tasarım Sorunları Doktora Programı.

De Certeau, M. (1988) The Practice of Everyday Life. London and Berkley: The University of California Press.

De Nardi, S. (2014) "Senses of Place, Senses of the Past: Making Experiential Maps as Part of Community Heritage Fieldwork", Journal of Community Architecture and Heritage, Cilt, Sayı 1, s. 5-22.

Duru, D. (2018). “Performans Olgusu Bağlamında Beden Mekân iliş̧kilerinin Araştırılması”, Basılmamış Yüksek Lisans Tezi, İstanbul Teknik Üniversitesi Fen Bilimleri Enstitüsü, Mimarlık Yüksek Lisans Programı.

Gibbons, J. (2007), "Mapping and Memory: Contemporary Psychogeographies", [çhttp://raco.cat/index.php/Waterfront/article/view/218363/297454 [Erişim tarihi 15 Ağustos 2017]

Güney, D., Arıdağ, L. (Kasım-Aralık 2011) "Yerin Deneyimlenmesi: KAYAKÖY", Mimarlık, Sayı 362, s. 1-3.

Hadjiphilippou, P. (2013) "The Contribution of the Five Human Senses Towards the Perception of Space", https://www. academia.edu/2460561/The_contribution_of_the_five_human_senses_towards_the_perception_of_space_by_Panagiotis_Hadjiphilippou [Erişim tarihi 17 Ekim 2016]

Holl, S. (1998) Intertwining. Princeton Architectural Press. New York.

Holl, S. (2000) Parallax. Princeton Architectural Press. New York.

Holl, S., Pallasmaa, J. \& Pérez- Gómez, A. (2006). Questions of Perception: Phenomenology of Architecture. William Stout, San Francisco, CA.

Kennedy, J. M. \& Juricevic, I. (2003). “Optics and haptics”, https:// semioticon.com/virtuals/multimodality/kennedy.pdf [Erişim tarihi 19 Aralık 2003]

Klatzky, R.L. \& Lederman, S.J. (1995) "Identifying Objects from a Haptic Glance. Perception and Psychophysics, Cilt 57, s. 11111123.

Kürkçüoğlu, E., Ocakçı, M. (2015) “Kentsel Dokuda Mekânsal Yönelme Üzerine Bir Algı-Davranış Çalışması: Kadıköy Çarşı Bölgesi", MEGARON, Cilt 10, Sayı 3, s. 365-388. DOI: 10.5505/ MEGARON.2015.02486

Merleau-Ponty, M. (2002, ilk basım 1962) Phenomenology of Perception, Colin Smith, Routledge (trans.), London \& New York: Routledge Yayıncılık.

O’Neill, M. E. (September 2001), “Corporeal Experience: A Haptic Way of Knowing", Journal of Architectural Education, Cilt 85, Sayı 1, s. 3-12.

Özcan, B. (2003). "Mekânın İçinde ve Dışında Olmanın Fenomenolojisi", Basılmamış Yüksek Lisans Tezi, İstanbul Teknik Üniversitesi Fen Bilimleri Enstitüsü, Mimarlık Yüksek Lisans Programı.

Pallasmaa, J. (1998), "The Space of Time”, Oz, Cilt 20, s. 54-57. URL: http://dx.doi.org/10.4148/2378-5853.1324

Pallasmaa, J. (2003). "Thought, Matter and Experience”, El croquis (genişletilmiş baskı), Mexico: Arquitectos Publishing, s.48-69.

Pallasmaa, J. (2014) Tenin Gözleri: Mimarlık ve Duyular (çev. A. U. Kılıç). İstanbul: Yapı Endüstri Merkezi Yayınları. (Orijinal yayın 2005).

T.C. Kültür ve Turizm Bakanlığı (Ekim 2011) “istanbul Tarihi Yarımada Yönetim Planı" http://www.alanbaskanligi.gov.tr/files/ 
Y\%C3\%B6netim\%20Plan\%C4\%B1_24\%C5\%9Fubat2012_k. pdf [Erişim tarihi 21 Mart 2016]

Yorgancioğlu, D. (2004). "Steven Holl: A Translation of Phenomenological Philosophy into the Realm of Architecture", Basılmamış Yükseklisans Tezi, Orta Doğu Teknik Üniversitesi Mimarlık Bölümü.

\section{Resim Kaynakları}

Global Urban Humanities: City of Memory,

https://globalurbanhumanities.berkeley.edu/city-of-memory

[Erişim tarihi 10 Mart 2016]

Çalıştay fotoğrafları çalıştay ekibinin özel arşivlerinden alınmıştır. 